anthropology \& materialism

\section{Anthropology \& Materialism}

A Journal of Social Research

$2 \mid 2014$

The Persistence of Myth

\title{
Seeing through the Fog of Myth
}

Walter Benjamin's Chromatics of Guilt, Debt, and Shame

\section{Takaoki Matsui}

\section{(2) OpenEdition}

Journals

\section{Electronic version}

URL: http://journals.openedition.org/am/405

DOI: $10.4000 / a m .405$

ISSN: 2364-0480

Publisher:

CETCOPRA, CRASSH - Center for Research in the Arts Social Sciences and Humanities, Fakultät Gestaltung - Universität der Künste Berlin

\section{Electronic reference}

Takaoki Matsui, «Seeing through the Fog of Myth », Anthropology \& Materialism [Online], 2 | 2014,

Online since 15 April 2014, connection on 19 April 2019. URL : http://journals.openedition.org/am/405 ; DOI : 10.4000/am.405

This text was automatically generated on 19 April 2019.

Tous droits réservés 


\title{
Seeing through the Fog of Myth
}

Walter Benjamin's Chromatics of Guilt, Debt, and Shame

\author{
Takaoki Matsui
}

\section{Introduction}

In his notes to the Theses on Philosophy of History, Benjamin stated that a "redeemed humanity" would be as unimaginable as the colour of ultraviolet rays (1974f: 1232). He did not solely consider ultraviolet rays to be metaphors; colour was an important subject in his early works on art and myth. He classified visual images based on their relationship to bodily activities. He attempted to understand the ways in which the mimetic activities of children and adults are affected by gravity. He also studied feelings of guilt and shame. In the present article, we study the ways in which Benjamin observed the mythic appearance of colours in these relationships (see, Section 1). We examine his views of modern society as a mythic world. We also examine his description of the transitory appearance of colours as possible moments of resistance to the mythic forces. His idea to turn shame against the mythic rule of guilt and debt led him beyond the limits of chromatic observation (see, Section 2). Finally, we trace the continued chromatic observations of modern society found in his late "materialistic" writings (see, Section 3). This study reconsiders Benjamin's belief in Marxism in relation to his early philosophical writings.

\section{Guilt and Shame in the Early Aesthetics}

2 Benjamin made an anthropological distinction between line and colour in his Outlook into Children's Books (1926) ${ }^{1}$. He stated that the human body imitates contours of things by dancing and drawing while it

cannot produce colour. It relates to it [...] in the shimmering colours of the eye. (Anthropologically speaking, sight is the watershed of the senses because it perceives colour and form simultaneously. And so, on the one hand, the body is the organ of active relations: the perception of form and movement, hearing and voice. 
On the other hand, there are the passive relations: the perception of colour belongs to the realms of smell and taste. [...]) (1972f: 613f.).

The sense of sight has active and passive mimetic potential for both drawing and colour perception on the "watershed" of the senses. This view was prefigured in his texts Painting and the Graphic Arts (1917) and Sign and Mark [Zeichen und Mal] (1917). In those texts, he speculated on the "mythic roots" (1977h: 603) of lines and colours. He classified them under the dichotomy of horizontal "sign" and vertical "mark". Although he never published them during his lifetime, he retained the same ideas and paraphrased them in the paralipomena to his essay, The Work of Art in the Age of Its Technical Reproducibility (1989b: 675f.). In my view, his theory can be summarised as follows:

4 "Signs" such as letters and graphic lines are preferably written, printed, drawn and read on the horizontal plane because this method can reduce the burden of gravity. However, as adults, we weigh too much to bend over the horizontal plane as we paint large-scale pictures. Instead, we can extend our long arms onto the vertical plane. Further, "absolute signs" exist that do not relate to the horizontal plane. Examples include the sign of Cain and the sign that the Israelites attached to their houses during the Tenth Plague. These examples demonstrate the "mythological essence" of the sign. The sign apparently belongs to a "wholly unknown order", exemplified by the release of Cain and the Israelites' moves (horizontal) to foreign cities or countries without resulting punishment or plague (1977i: 604). These signs can be distinguished from "marks" [Male] such as moles, mottles, birthmarks, Christ's stigmata and leprous symptoms. Marks show their "mythic nature" by their entanglement of the marked person in their "temporal magic" (i.e. in the collective chain of guilt and atonement). They are considered "absolute" marks because they do not necessarily relate to the vertical plane. However, they are often subjected to vertical movements (e.g. the Descent and Ascension of Christ) in panel or mural painting. Painting [Malerei] differs from the active mimesis of graphic signs because it is rooted in the involuntary appearance of coloured Male. However, painting must transcend, by virtue of its "composition", the "temporal magic" with which marks are transferred or transmitted. Last but not least, some colours do not belong to marks (i.e. watercolours and other transparent colours such as those used in book illustrations). Unlike opaque oil colours, these transparent colours allow underlying drawings or graphic outlines to remain visible (1977i: 605f.).

Therefore, colour is not simply the passive part of our mimetic faculty. It can also be combined with graphic activities (e.g. drawing, writing, and printing) when its application is transparent. The "shimmering colours" of the eye symbolised this ambiguous position in the quoted essay. Coloured illustrations stand on the child's "watershed of the senses". Benjamin had already thematicised the difference between transparency and opacity in his earliest writings on colours (e.g. The Rainbow: A Dialogue on Fantasy of 1915-16). In these works, he contrasted "colours of the painter" (oil colours) to the "colour of fantasy"; the former appear opaque and invariable; the latter appears transparent, translucent, or transitory ${ }^{2}$ (1989a: 21, 24f.). To a certain extent, this distinction between painterly and fantastic colours corresponds with distinctions made between "surface colour" and other modes of colour appearance in Gestalt psychology. The surface of most objects appears as if it contains invariable colours despite the fact that the surface incessantly reflects changing light waves. This does not occur in other modes of appearance such as film colour, lustre, luminosity, and glow (cf. Katz 1911). When we view a transparent liquid, the glow of red-hot coals, or the blue sky, we take the 
possible colour changes into account. Like many psychologists, Benjamin became interested in the vision of the infant who had not yet learned to tell objects apart from each other by the use of colour constancy. Unlike psychologists, however, he did not regard the perception of colour constancy as a developmental accomplishment. Rather, he saw it as the loss of "innocence" because, as adults, we cannot play as enthusiastically with the transitory colours of soap bubbles and magic lanterns as small children can. He did not examine the psychological nature of colour constancy. Instead, he associated this loss of innocent joy with the Fall of Man. He described the "colour of fantasy" as the colour of the Paradise (1985e: 124f.; 1989a: 562). Further, in his well-known essay on human language, he described the development of man's verbal recognition as a consequence of the Fall (1977a: 153ff.). Once adults lose sight of the "colour of fantasy", their perspective was supposedly overshadowed or clouded with mythological, judicial or moral notions such as "guilt" and "shame" (1985c: 111f., 1985e: 124). Benjamin attempted to escape this cloud of recognition by his reflections on the colour of the rainbow, the “innocent" blushing of children (1989a: 24), and the illustrations in children's books.

6 He again addressed and revised this idea two years later in Sign and Mark. He did not presume children's innocence. Rather, he believed the difference between children and adults is rooted in the fact that children prefer the vertical to the horizontal picture plane as they gain weight and height. He also dissociated the act of blushing from the innocence of childhood. He regarded it as a kind of "mark" which "dissolves" one's personality into "certain of its basic components" (1977i: 605) because it exposes one's errors to the public eye like the colour of figures in the 'cloudy' composition of religious paintings ${ }^{3}$. After this revision, he further changed his view of blushing and reformulated his distinction of transparent and opaque colours based on Goethe's Theory of Colours (1810).

7 Goethe argued that colours originate from the polarity of light and darkness in the turbid [trüben] medium. He believed that colours appear only in more or less cloudy or murky (and not completely transparent) spaces or bodies (Goethe 1991: 73, 82 [\$148, 178]). Benjamin probably understood this as Goethe's disregard for transparent colours and searched for its remedy in a remark made by Philipp Otto Runge that was quoted in Goethe's book:

Transparent colours are infinite in their brightness or darkness, just as fire and water can be regarded as their zenith and nadir. [...] Opaque colours are like flowers that do not dare to compete with the sky, yet are concerned with weakness on one side and with evil on the other: with white and black. They are ... capable of such graceful variations and can produce such natural effects that ... transparent colours, in the end, only play like spirits over them and serve only to raise them (cited in Benjamin 1972f: 614).

Runge was fascinated by transparent colours because of their spiritual potential and their transitory nature ${ }^{4}$. Goethe became interested in this remark but he only included it in his book as a "supplement" because of its incompatibility with his own theory of turbid mediums. Nevertheless, Benjamin quotes this passage in his essay as if it were Goethe's own remark. Thus, Benjamin authorises his own evaluation of transparent and transitory colours in Goethe's name. In addition, he suggests that the colour sense of illustrators could be raised from the opacity of black-and-white printed matter to the heavenly transparency of children's fantasy. He stated that the latter radiates in the former when "the eyes and cheeks of children poring over books are reflected [widerstrahlen] in the glory of the sunset" (Benjamin 1972f: 615) (i.e. in the sunset depicted there). The sunset 
scene must be available to reflect hypothetical rays of light on its transparently coloured surface. This image corresponds to the motto of the essay taken from his friend Fritz Heinle: "Green flashes already in the evening red" (1972f: 609).

Book illustrations simultaneously help lead children to the black-and-white surface of texts and to the sphere of literacy: "If the child's imagination sinks into a reverie over finely coloured copper engravings, the black-and-white woodcut, the plain, prosaic illustration, leads him out of himself" (1972f: 610). In another essay on children's books, he regards plain illustrations of alphabet books as a "polar complement" to finely coloured prints. Children are supposed to grow out of their colourful dreams by virtue of this polarity: "In the realm of colourless pictures, children awaken, just as they dream their dreams in the realm of colour" (Benjamin 1972a: 20f.; cf. 1985d: 113). The "realm of colourless pictures" includes black-and-white letters and graphic lines. It also, supposedly, reflects invisible rays. This is an anti-Goethean polarity. Goethe could not acknowledge Johann Wilhelm Ritter's discovery of ultraviolet rays because invisible rays had no place in his theory of the colour wheel. Benjamin, by contrast, became fascinated by Ritter's speculations on light (1974b: 387). In One-Way Street, he further compared invisible rays to a prophetic commentary on the "book of life": Invisible signals of luck "pass day and night through our organism like wave impulses" (Benjamin 1972c: 141f.). If we fail to retrieve them each morning "on waking", we will only discover their traces afterwards, like those of "ultraviolet rays" on our body, with regret or with "a feeling of guilt" (1972c: 141f.).

In opposition to Goethe, he also assumed the effect of invisible rays upon blushing. In Paragraph 666 of the Theory of Colours, Goethe considered the colours of living things as the expression of their insides. In a discussion of this view that appeared in a fragment written around 1920 (On Shame), Benjamin refused to regard blushing as an expression of one's emotion:

The redness of shame does not well up from the interior [...] but, rather, gushes from outside onto the one who is ashamed and extinguishes the disgrace and simultaneously withdraws him from disgracing. For the dark red with which the shame douses him draws him under a veil and withdraws him from the gaze of human beings (1985a: 69f.).

11 He sees a relationship between the "dark red" of blushing and the "pure essence of colour" which supposedly lies beyond Goethe's "clouding [trübend]" view. This pure essence does not exist in the expressiveness of the organism (e.g. flowers, fruits, or animal skins). Rather, it exists in a "ray" of light which "assembles [...] only on the human face' 'with the dark red when it has stopped its radiation. [...] Expressionless but significant appearance of extinction is the red of shame' (Benjamin 1985a: 71). Here, blushing appears similar to a suntan which serves, contrary to the mark of moles or freckles caused by sunburn, to provide protection from the destructive sunbeam. It seems to prevent, by virtue of invisible rays, the ashamed person from being dissolved in the marked cycle of guilt and atonement $t^{5}$. It was just this kind of purity that Benjamin felt was missing in the "cloudy" appearance of Ottilie, the mythic heroine of Goethe's Elective Affinities. Benjamin notes that her "plant-like" muteness is far removed from shame and other human passions (1974a: 175, 184, 192).

In the next section, we examine Benjamin's descriptions of this and other kinds of interaction between rays and bodies in his writings from the same period. In my view, these writings were the result of efforts to find an image of what he then referred to as 
"bare life". He coined the term "bare life" in response to Georg Simmel's conceptions of life and fate ${ }^{6}$.

\section{Coloured Masks and Shelters in the Nexus of Guilt and Debt}

In The View of Life (1918), Simmel argued that an individual succumbs to "fate" when a series of events "deeply" touches the individual's life. The individual then feels as if he or she "had chosen" the event because of its "affinity" to the individual's intention. Thus, the individual's life seems to be tied to an uncanny network of events (Simmel 1999: 320ff., 317). Although he did not refer to this book, Benjamin adopted and modified Simmel's terminology in the essay Fate and Character. He made a distinction between an individual's view of "fate" and an individual's "character". Although Simmel spoke of an individual's deep contact with fateful events, Benjamin argued that fate affects the individual's "bare life". Life's bareness lies in its vulnerability; it can be as deeply touched by fortune-tellers as by judges. If an individual were to consider a chosen object, such as a card or a planet, as something providentially assigned to him or herself, the individual would then integrate the object into what Benjamin calls the "guilt context". The guilt context is the nexus of past and future established by abstract equivalence between guilt and atonement. This type of contextualisation would be quite oppressive if it were imposed as a judicial sentence. Benjamin argues that the 'best part' of the human being remains "invisible" in this temporal nexus of things and events. To "take a completely transparent picture [Durchleuchtung]" of what vaguely appears to be the deep centre of life, such as an X ray which penetrates the body, one has to "fix the particular kind of time in fate" (Benjamin 1977b: 174-176).

Simmel remained content in his vision of the ways that tragic heroes confirm their fate with their remarkable self-destruction. In response to Simmel's remarks on the absence of "moral world order" in tragedy (Simmel 1999: 323), Benjamin stated that tragedy breached demonic fate only when 'the head of genius lifted itself from the fog of guilt' (1977b: 174f.). Thus, Benjamin became intrigued by the "liberating" vision of Molière's comedies. He grew fascinated with the character of the miser and/or hypochondriac who "opens up like a sun" in the "brilliance of its single trait, which allows no other to remain visible in its proximity". The "freedom" of their actions becomes visible in their "beams" (Benjamin 1977b: 178) when we realise that their lives are only temporarily overcast by their restless petty self-estimation (e.g. financial prognosis or medical prescription). The miser could change his vision with his funny glasses. The hypochondriac could recover from depression as quickly as he could recover from his pretended death (cf. Benjamin 1977j: 613). Any fateful view of these character's lives, just like their makeup, could be fixed and removed.

This radiographic view opposed Simmel's view. Simmel thought that an individual's character traits (such as "miserliness") could be observed like coloured marks in the "network" of a painterly composition (1999: 394f., 397-399). In Benjamin's view, those marks would sink in the foggy view of fate. On the contrary, the character trait of the comic figure is "the sun of individuality in the colourless (anonymous) sky of man". It only temporarily casts "the shadow of the comic action" (Benjamin 1977b: 178). Benjamin finds a similar radiological fixation in the narrative structure of Goethe's Elective Affinities. 
He regarded its main story, forbidden love affairs foretold in the name of chemical "affinities", as a turbid (though "peculiarly diaphane") realm of "mythic" fate. Its "colours" do not fade until they receive a sharp illumination of "freedom" and transparent "anonymity" from the inserted novella (Benjamin 1974a: 132, 135, 169, 192, 196f.) $)^{7}$. Thus, he blames the main characters because they are victims of "bare life". He praises the "enlivening [belebende] power" of the novella (Benjamin 1974a: 139, 169). The couple that appear in the novella is not enlivened from inside. The power of their "radiation" appears in their wedding clothes which overshadow their personal traits (Benjamin 1974a: 170). They recover from their bareness with their temporarily comical appearance.

In the same manner, Benjamin's Critique of Violence implies his response to Simmel's notion of law. In The View of Life, Simmel regarded law and economy as "forms" of "life" which transcend life itself. Although the "vital significance" of the "life-whole" pervades social systems like blood [durchblutet], law and economy emancipate themselves from the original significance of life and take into themselves "forces and contents as they pulsate in the rest of life" (Simmel 1999: 289). Benjamin may have had this image of pulsation in mind when he asserted, in his reference to the legend of Niobe, that "blood is the symbol of bare life" (Benjamin 1977c: 199). After Apollo and Artemis murdered Niobe's children in revenge for her arrogance, the children's death established a law-like cycle of guilt and atonement:

Although it brings a bloody death to Niobe's children, it stops short of claiming the life of their mother, which she leaves behind, more guilty than before through the death of the children, both as an eternally mute bearer of guilt and as a boundary stone on the frontier between men and gods (1977c: 197).

Thus, in the eyes of their mother, the opaque colour of the children's blood symbolised "bare life". The same holds true for the life of the protagonists of Elective Affinities. Benjamin compared its "mythic" plot with a "bloody ditch". Goethe seemed to stand before this ditch "like Odysseus with naked sword" to fend off "the thirsty shades" in pursuit of pictorial beauty. With the use of Goethe's own phrase, Benjamin also noted that the novel embarrassed readers like the bloody "robe of Nessus" (1974a: 179, 141).

Blood played a different role in the act of blushing. The dilation of blood vessels did not expose one's emotions to the public. Benjamin believed that the dilation made one's white (half-transparent) skin ${ }^{8}$ impenetrably opaque. Instead of radiating like the masquerade of comedians, blushing saves one from bareness, from exposure, because radiation darkens the skin. However, this does not necessarily mean that blushing helps an individual resist the fateful rule of "bare life". As we will see, Benjamin continued to observe the ambiguity of blushing and flushing in his later writings.

We must ask: how does Benjamin grasp our economic life? Economic life appears to be another mythic (quasi-religious) nexus that consists of debt and payment. Major religions worldwide have developed the nexus of guilt [schuld] and atonement. In addition, money enables (or drives) us to develop a worldwide network of debts [Schulden]. Therefore, in the fragments written around 1921 entitled (by editors), Capitalism as Religion, Benjamin described capitalism as an incessantly debt-producing [verschuldend] system. However, he argued that we are verschuldet to a hidden "immature deity" of capitalism (Benjamin 1985b: 101). He characterised this deity as a "parasite" that has eaten its way through the history of Christianity. Further, he compared "icons of various religions" to "banknotes of 
various countries". Unlike icons, banknotes made the pagan "Spirit" "speak out of the ornamental lines" (Benjamin 1985b: 102) and not out of a deified personality.

Indeed, banknotes can incorporate immature and impersonal traits of the capitalistic debt-production and these traits may not have been just ornamental ${ }^{9}$. They originated in promissory notes. These personally registered notes became generally transferrable and were circulated like coins. They were never returned to their issuers for the promised payments. Therefore, they represented generalised immature debts. Benjamin did not accidentally write this during the years of accelerating inflation. At that time, banknotes served only to increase debts in the flood of fiat money (which was inconvertible to gold). Their true nature was disclosed during the hyperinflation. In one of the Capitalism fragments (published separately), Benjamin compared money to rain that suggested an apocalyptic flood of inflation (1972c: 941).

This ominously cloudy view of capitalism may well have motivated Benjamin to study the Parisian arcades. Strollers could take shelter from the rain in these arcades while merchants could hopefully secure constant sales despite the unstable weather and economy (1982: 83 [A1, 1]). In a crucial note for The Arcades Project, Benjamin described the arcades' temporal structures. What was once referred to as the "colour of fantasy" dawns on the dreamy strollers whose vision is clouded by the retrospective vision of adults:

Boredom [Langeweile] is a warm grey fabric lined on the inside with the highest blaze of colourful silks. In this fabric we wrap ourselves when we dream. We are at home then in the arabesques of its lining. But the sleeper looks bored and grey within his sheath. And when he later wakes and wants to tell of what he dreamed, he communicates by and large only this boredom. For who would be able at one stroke to turn the lining of time to the outside? Yet to narrate dreams signifies nothing else. And in no other way can one deal with the arcades - structures in which we relive, as in a dream, the life of our parents and grandparents, as the embryo in the womb relives the life of animals. Existence in these spaces flows then without accent, like the events in dreams. Flânerie is the rhythmic of this slumber (1982: 161f. [D2a, 1]).

Rather than childlike innocence, strollers enjoy the possession of money. Money seems to promise a burden free life similar to the life of an embryo that floats in amniotic fluid. When the strollers dream of the colourful commodity world of their childhood, they hope, like growing embryos, to repeat the cosy bourgeois life of their ancestors. Their well-being depends on the fertility of interest-yielding assets. These assets are sustained by the systematic renewal of debts on the financial market. No one could indulge in slumber in view of the threatening devaluation of the assets. Baudelaire must have been aware of the insecurity of this system because he lived in debt and was constantly on the run from creditors. As a legally incompetent squanderer, he received-like an undernourished embryo-only a meagre allowance from his trustee. The arcades only seem to cover the vulnerable bodies of the visionary strollers. We must ask: how does this greyish debt-producing system relate to the colourful "arabesques of its lining"?

The womblike image of the arcades is reminiscent of Simmel's notion of life. The "pulsing" forces of life might now be taken into the rhythm of urban economy (i.e. the fashion and business cycles). Dreamers are entangled in the fateful recurrence of outdated fashion because of their allegedly personal affinities to it; their seemingly tasteful choices dissolve their personality into a set of colourful commodities. Further, their colours consist of a warm grey fabric with a colourful lining. This is reminiscent of another 
analogy employed by Simmel. In Philosophy of Money (1900) and other sociological writings, Simmel compared money to colourless light because a far broader "spectrum" of goods can be acquired with money than by barter: "The possession of money radiates in the diversity of trade and consumption, and unifies in itself the whole wealth of economic life, just as the colourless appearance of white light contains the whole spectrum of colours in itself" (Simmel 1989a: 291). The owner of money enjoys the "pregnant moment" in which "innumerable threads get entangled before coming loose again in the next moment into countless effects" (1989a: 292). Despite or just because of the apparent colourlessness of money, this monetarily "pregnant" texture covers the colourful "blaze" of the commodity world in the "warm grey" tone described by Benjamin.

It appears to be warm because money gains a special quality by its designation of qualitatively different objects which can be exchanged for others: "As long as money serves in our consciousness as the only and closest goal of our endeavours it still possesses a quality. [...] The concentration of thoughts on it, the liveliness of the attached hopes and emotions shine on it with a warmth that lends it a colourful glow" (Simmel 1989b: 339). However, this special quality covers everything with a dull grey tone that paralyses our feeling for value differences:

Whoever has become possessed by the fact that the same amount of money can procure all the possibilities that life has to offer must also become blasé. [...] The more the acquisition is carried out in a mechanical and indifferent way, the more the object appears to be colourless and without interest [...] (Simmel 1989b: 335).

The particular charms of the objects fade away "because we acquired them by an indifferent method which effaces their specific value" (1989b: 335f.). Thus, the blasé person "experiences all things as being of an equally dull and grey hue, as not worth getting excited about" (1989b: 334f.). In The Metropolis and Mental Life, Simmel also argued that this economic blasé attitude coincides with its physiological counterpart: the protective reaction of city dwellers to overstimulation (1995: 121f.).

This greyness resembles Benjamin's image of boredom ${ }^{10}$, but only superficially. In his letter to Adorno dated 23 February 1939, he stated that 'one can find much that is interesting in the book [Philosophy of Money] if one is resolved to disregard its basic thoughts' (Benjamin 2000: 227). We could trace the more substantial influence of three other authors on his dreamlike image of the turbid urban space: Ludwig Klages, Alfred Kubin and Paul Scheerbart.

Klages is known for his antirationalistic idealisation of prehistoric matriarchy. He attempted to discover remnants of matriarchal elements in modern society based on his assumption that the patriarchal spirit of capitalism already suppressed matriarchy in the myth of Hercules. For example, he applied the dichotomy between organic "rhythm" and mechanical "metre" [Takt] to analyse the drowsiness of railway passengers. He noted that the mechanical vibration of train seats pacified them like the rhythmical heartbeat of expectant mothers (Klages 1974: 523f.) ${ }^{11}$. Kubin parodied this retrospective vitalism ironically. The "Dream Kingdom" portrayed in his novel The Other Side (1909) is a backward despotic state built and ruled by an old school friend of the protagonist. It resembles a womb in its climate and its vaginal symbolism (Schumacher 1982: 27). The protagonist is lured into this kingdom by a generous cheque from the ruler. The protagonist falls under the influence of his "rhythmic heartbeat". The ruler uses his ability to make people fall asleep when a hostile intruder, "the American billionaire" 
Hercules Bell, attempts to turn them against their master. Bell symbolises the antivitalistic tempo of modern capitalism with his surname. The kingdom is destroyed after the gold reserve is lost during a power struggle between them (Kubin 1968: 148, 172, 217).

This story inspired Benjamin to compare money to rain. He contrasted the darkness and humidity of Kubin's city with the transparency, luminosity, and aridity of the asteroid depicted in Scheerbart's novel Lesabéndio (1913) (Benjamin 1972c: 941). The inhabitants of this almost gravity-free asteroid devote (or even sacrifice) themselves voluntarily to the construction of an innovative steel tower. Despite its contrast to Kubin's mammonistic kingdom, their democracy seems to suggest that the coming moneyless society might also possess totalitarian traits (Matsui 2008: 306f.). The Parisian arcades must have reminded Benjamin of these dreamlike stories. The arcades were also built and destroyed in the struggle between mammonism and social utopianism. Benjamin quoted Louis Aragon who described the arcades' demolition as a violent penetration of the womblike "human aquariums" by the "great American passion for city planning" (1982: 669 [R2,1]). The resemblance to Kubin's story is unmistakable.

This literary constellation suggests the differences between Simmel's blasé person and Benjamin's strollers. The blasé person simply becomes desensitised by the flood of money and commodities. The dullness of the strollers could hide their anxiety about the uncertain future of debt-increasing capitalism. The strollers were reluctant to look beyond capitalism as long as it seemed to retain its fertility. Benjamin himself had been struck by capitalism's partial breakdown during the hyperinflation. In One-Way Street, he complained that the notes [Scheine] showed off its 'almost unbearably piercing clarity'. In this way, he ironically distorted Simmel's analogy: Rather than uniting colourful commodities as luminously as the sunshine on the market, scheine faded away as the measure of exchange value and exposed their owners (i.e. no less than beggars who received them in the street) to the shameful "naked misery" (1972c: 96). Scheine were stripped of their semblance [Schein]. They were revealed to be nothing more than humanity's common debt to the future. Just as Kubin's immigrants became dependent on deceptive gifts (cheques), the hyperinflation caused German citizens to become beggars that depended on recklessly issued notes. The economy fell back into the mythic state, because "as long as there is still one beggar, there still exists myth" (1982: 505[K6,4]). Based on this view of "naked misery", Benjamin attempted to "turn the lining of time" and break the cycle of capitalistic debt-reproduction. He observed both the opaque appearance and the colourful inner "blaze" of the commodity world under changing light to learn how humanity's shameful economic bareness could be transformed.

In his Berlin Childhood around 1900, he depicted the colours of things during changing weather. He relates how his seemingly innocent childhood was already overshadowed by the capitalistic economy. However, he also exposes the images of his childhood to historical and optical change. He presents the example of the stairwell of a mansion in the mythic "labyrinth" of Tiergarten (Benjamin 1989c: 393): As he passes under its stained-glass window, he experiences an overlap of verticality and horizontality, and activity (ascending and descending) and passivity (resting at the landing) in the colourful light. As he strains his ears to hear both his heartbeat and the patter of raindrops, he compares them to the tempo of industry inscribed in Schiller's well-known Song of the Bell. He does not adopt its bourgeois discipline. He condemned the bourgeois discipline in his Program for a Proletarian Children's Theatre as a 'mark of shame' [Schandmal] (Benjamin 
1977k: 768). Rather, he raises the straps of his school satchel as if it were as light as the wings of the resting cherub of the Sistine Madonna (Benjamin 1989c: 394f.; Matsui 2008: 341-346). At this point, he might be dreaming of an almost gravity-free space such as Scheerbart described on his asteroid. However, it still resembles the wings of Icarus. The mythologically decorated cityscape also causes him to consider Hercules' deeds (and, perhaps, the deeds of Hercules Bell) as allegories of the declining bourgeois society ${ }^{12}$.

The precocious narrator also dares to talk to street girls in the same "labyrinth". Benjamin is struck by a deafening rush of blood to his ears. His blushing does not save him from involvement in commercialised intercourse during the following years (1972d: 287f.). Therefore, he has reason to reconsider the function of shame in the economic context. When he described the payment of bashful whoremasters in a fragment of The Arcades Project, he modified his former view that a fading ray of light causes facial blushing to act as a shield. Instead, he finds the same function in the fading lustre of wellthumbed coins. He argues that the tips of guests are not just charitable gifts. The tip is the essential part of the payment because "no girl would choose to become a prostitute if she counted solely on the stipulated payoff from her partners". Their tips cause and cover up their shame. When they realise that a small tip would only betray their shamelessness, they are forced to cover it with many more coins:

There are as many nuances of payment as there are nuances of lovemaking [...]. The shame-reddened wound on the body of society secretes money and heals up. It forms a metallic scab. [...] Impudence throws the first coin onto the table, and shame pays out a hundred more to cover it (1982: 615 [01a,4]).

Unlike the newly issued notes [Scheine] of inflated currencies, well-thumbed coins are supposed to cover our shameful conduct like a darkish scab. This does not necessarily signify redemption from the mythic world of economy. In an aphorism written in 1929, Benjamin compared shameful experience with a mythic bath in "dragon's blood" (1972e: 372). Moreover, Benjamin looked beyond the chromatic phenomena of shame. In his essays on Robert Walser (1929) and on Kafka (1934), he supposed that their bashfulness [ Scham] drove them to the Sisyphean labour of writing (1977d: 325f.; 1977e: 428). Shame inscribed their struggle with the mythic view of fate in the very act of writing. Therefore, the social function of shame cannot be determined within the limits of chromatic analysis.

\section{In Search of a 'Serene' View}

We will now discuss whether Benjamin's observation of changing colours played an important part in his controversial "anthropological materialism". The controversy began with Adorno's critical response to the essay The Storyteller (1936). His criticism becomes more intense in 1938 (Lonitz 1995: 193, 368). What was at stake in the logic of The Storyteller? In the essay, Benjamin classifies three forms of communication. Storytelling is a traditional form of collective communication. It can be distinguished from newspapers and novels. Benjamin argues that newspapers do not have the potential to break the "boredom" of readers from within. Newspapers do not even allow readers to retain what they have learned in the state of "slumber". Readers also lost the skill of storytelling when they lost the time to listen to others: "Storytelling is always the art of repeating stories, and this art is lost when the stories are no longer retained" (1977f: 446f.). 
Benjamin then compares this "art of repeating stories" to craftsmanship. He states, storytelling

does not aim to convey the mere content of the thing, like information or a report. It sinks the thing into the life of the narrator [Berichtenden], in order to bring it out of him again. Thus traces of the storyteller [Erzählenden] cling to the story the way the handprints of the potter cling to the clay vessel (1977f: 447).

Adorno may have regarded this emphasis on handprints as a crude example of Benjamin's "gesture of immediacy" (Lonitz 1995: 193). However, the point lies not so much in the handprint itself. It lies in the appearance of the glaze that covers it. Benjamin suggests this with a quote from Valéry who states that the art of storytelling corresponds most precisely to "lacquer works or paintings in which a series of thin, transparent layers are placed one on top of the other" (1977f: 448). The "handprints" of the narrator change his seemingly neutral ("transparent") relationship to the reported story because they cause irregular reflexions on its surface. The "life of the narrator" can gain the lustre of narrative glaze even if it retains opacity in its bare (uncovered) state.

To distinguish stories from novels, Benjamin then applies the analogy of fire. Stories and novels are digested or burned by consumers in different ways: A story is shared (in reality or in the imagination) by listener and storyteller. However, the isolated novel reader

seizes upon its material more jealously than anyone else. He is ready to make it completely his own - to devour it, as it were. Indeed, he destroys, swallows up the material as a fire devours logs in the fireplace. The suspense which permeates the novel is very much like the draft of air which fans the flame in the fireplace and enlivens its play (1977f: 456).

The material of the novel is the "fate" of its characters. It "yields to us, by virtue of the flame which consumes it, the warmth which we never draw from our own fate. What draws the reader to a novel is the hope of warming his shivering life with a death he reads about" (Benjamin 1977f: 456f.). Therefore, Benjamin compared his own reading of Elective Affinities with the lively fire employed by alchemists. He looked for "hope" in the figure of a falling fiery meteor (Benjamin 1974a: 126, 200f.) that doomed Ottilie, the personification of fire, to death. Thus, the reader is supposed to appreciate the novel at a distance.

In contrast, those who listened to stories could be burned along with the storyteller "who could let the wick of his life be consumed completely by the gentle flame of his story" (Benjamin 1977f: 464f.). The violence of the narrative "flame" stands under collective control; they receive narrative fuel from the storyteller who also received fuel from hearsay. Therefore, "the wick of his life" is soaked not only with his own experiences. It is soaked with the experiences related by others. The "flame of his story" is tinged with their voices as transparently as a piece of lacquer work with its thin layers. While "written history' describes events in "white light", storytelling sheds "spectral colours" onto them. The reader can hardly tell whether they appeared on "the golden fabric" of a religious picture or on "the multicoloured fabric of a worldly view" (Benjamin 1977f: 451f.).

Benjamin sees an eminent example of such uncertainty in Nikolai Leskov's The Alexandrite (1884), the story of a superstitious gem engraver who saw the "fate" of the murdered Tsar in the red flash of a green stone. The narrator wants to transport us into 'that old time when the stones in the womb of the earth and the planets at celestial heights were still concerned with the fate of men', but he immediately admits: “Today [...] everything 
has grown indifferent to the fates of the sons of men" (cited in Benjamin 1977f: 452).

Although stones are not exceptions, the belief of the protagonist was unshakable:

He suddenly squeezed my hand on which was the ring with the alexandrite, which is known to sparkle red in artificial light, and cried: « Look [...]! It was always green as hope and only toward evening was it suffused with blood. [...] But it concealed itself for a long time [...] and permitted itself to be found only on the day when Tsar Alexander was declared of age, when a great sorcerer had come to Siberia to find the stone $[. .]$.$» .$ free wine outside the city gate. According to a police report, on their way home, they displayed "their enjoyment - full of pride and defiance - as the only enjoyment granted them". Even women did "not hesitate to follow their husbands to the gate with their children" (Benjamin 1974c: 520). These proletarians remind us of Niobe and her children. In this case, they remained unpunished only because their provocative parade did not threaten the rule of the monarchy. Baudelaire must have recognised "a bit of himself" in this impotent defiance when he depicted the imperial behaviour of a drunken ragman. However, he did not recognise either his own or their economic situation objectively. He appears to have included them in the "race descended from Cain" (i.e. the race of "the disinherited' that was allowed to enter cities without punishment) (Benjamin 1974c: 522f., 526).

In this way, Benjamin observed the relationship between the sign (of Cain) and a kind of mark (flushing). In fact, he attempted to overcome the violent "swing" of his "esoteric" thinking, similar to the waxed wings of Icarus, in this essay (Benjamin 1974c: 1103). The relationship to his early thinking becomes more significant when we observe a peculiar parallel between this essay and his criticism of Elective Affinities. ${ }^{13}$ In the constellation of this essay, Baudelaire's flânerie is comparable to Goethe's morphology and optics. 

because of his reluctance to confront political and literary questions. Goethe asked readers of his Theory of Colours to close their eyes and sharpen their hearing because the readers' evasive introversion was required for his physiologically oriented optics (Benjamin 1974a: 148). The French counterpart of this attitude can be found in the "physiological" literature about the Parisian life which was very popular right after Goethe's death. Its leisurely style conformed to the idle flâneur. Benjamin puzzled Adorno when he stated that the flâneur "goes botanising on the asphalt" (Benjamin 1974c: 538; see also 1108). It is possible that Adorno could not follow Benjamin's association of Grandville's botanic caricature with Goethe's visionary morphology (cf. Benjamin 1972b: 152f.). Benjamin also pointed out that it became fashionable to take turtles for walks in the arcades (1974c: 556). This statement might have familiarised readers with the imaginary phylogeny of his strollers. The physiological literature also served as "blinkers" because they concealed the disquieting stimulations of city life. They helped them overlook "grey cobblestones" of the streets along with the despotic urban planning that served as their "grey background". Instead, they displayed "shiny enamelled shop signs" like an "oil painting" on the wall of a "living room" (Benjamin 1974c: 539f.). Further, they provided relief to entrepreneurs by their characterisation of annoying factory noises as cheerful accompaniments for workers. The Parisian physiologies attempted to suppress the anxiety of city dwellers by the simple narrowing of their eyesight and the idealisation of nasty noises, whereas Goethe disclosed his personal anxiety in one of his maxims (Benjamin 1974c: 540).

Baudelaire began his literary career after the decline of these physiologies. At that time, Paris appeared as a disquieting mass society. It served "as the asylum that shield[ed] an asocial person from his persecutors". According to a police report, an individual did "not have to blush in front of anyone" because an individual could remain "unknown to everyone else' in the densely populated area (Benjamin 1974c: 542). The supposed shielding function of blushing was replaced by the anonymity of the urban economy. As a result, the government took measures to illuminate the dark nests of criminals. Benjamin contrasts Baudelaire's Paris to the streets of London described in Poe's tale The Man of the Crowd. Poe's tale is "something like an X-ray of a detective story" (Benjamin 1974c: 550). By its reliance on narrative skeleton undecorated by crime, it describes how the storyteller, a convalescent man, chased a suspicious man. The clear eyes of the storyteller also observed businessmen with flushed faces smiling humbly in the street (Benjamin 1974c: 554f.). The quasi-criminological illumination of this tale [Novelle] stands in stark relief against the backwardness of Baudelaire's Paris just as the Novelle of Goethe's Elective Affinities, the story of a chased and reanimated hostile girl, cast a "bright light" on its mythic main story (Benjamin 1974a: 169, 192). In contrast to the incisive American novelist, Baudelaire attempted to retain the leisurely attitude of the flâneur in the twilight cityscape. As he strolled among the crowd, he vainly tried to forget that he was only a worthless commodity: an unpopular writer (Benjamin 1974c: 556f.). Because he could not identify with the masses as Hugo did, he isolated himself from the crowd and invented new types of heroes.

He dreamed, for example, of the heroic swordsmanship of proletarians who were flushed, with or without wine, in the bloody colour of the sunset. He fought against the classicistic tradition, with his modernistic manifesto, like an apache invested with the "sign of Cain" (Benjamin 1974c: 576f., 581f.). Yet his poetic cityscape also carried anachronistic "marks" 
of vulnerability (Benjamin 1974c: 586) because his apache-like heroism survived in the images of perished heroes such as Icarus. In his view, modernity had to match antiquity by its emphasis on ephemeral and transient beauty. Therefore, he conjured up mythic figures which made ephemeral appearances in the contemporary cityscape and became entangled in what Benjamin once called the temporal magic of marks. In this respect, he displays striking elective affinities with the etcher Meryon, because Meryon also surprises us with the strange appearances of marks under the misty sky (Benjamin 1974c: 591f.). Meryon developed schizophrenic delusions of murder and persecution. At times, he suffered hallucinations of an ocean of blood that surrounded his bed (Burty 1879: 19). He eventually compared himself implicitly to Oedipus and Icarus in his Eaux-fortes sur Paris (Matsui 2008: 267-283). His last etching was the design for a coffin-like upright bed in which one should sleep in a position similar to the crucified Christ. The bed was decorated to look like a Maori canoe. Meryon studied Maori decorations during his term as a cadet in the South Pacific. The Maori decorations were also indirectly related to Benjamin's notion of mark ${ }^{14}$. Therefore, Benjamin had reason to state that "Meryon turned the barracks of Paris into monuments [Denkmäler] of modernity" (1982: 487 [J91a,1]). Other viewers compared Meryon's etching needle to a rapier (1982: 304 [J2a,2]) because they were deeply impressed with the striking verticality of these "monuments". They owed their verticality no less to the elaborated manipulation of perspectives than to the use of allegories of downfall and crucifixion.

Benjamin must have had the author of Elective Affinities [Wahlverwandtschaften] in mind when he considered the two imaginary warriors, Meryon and Baudelaire, to be " wahlverwandt" to each other in the "scarlet colour" of their cityscape (Benjamin 1974c: 591f.) because Goethe stood, as already quoted, like Odysseus with a "sword" before a 'bloody ditch' and conjured the ghost of an ancient beauty (Benjamin 1974a: 179). However, unlike Goethe, Baudelaire developed his heroism into a series of masquerades. He appeared as an "eccentric individuality" and played various roles. They formed "a mask under which he tried to conceal - out of shame, one might say - the supraindividual necessity of his way of life and, to a certain extent, also his fate" (Benjamin 1974e: 690). He also used "the night sky of the metropolis" to conceal misery and "shame" in his poem (Benjamin 1982: 444 [J69a,2]).

We do not know how Baudelaire's fate was to be illuminated with the "scarlet colour" of Meryon's Paris and the aquarium-like "glaucous gleam" of Aragon's arcade (1982: 669 $[R 2,1])$. Benjamin could not complete his study. Despite its parallel to his essay on Elective Affinities, Adorno blamed it one-sidedly for its 'magic and positivism' while praising the essay on Goethe (Benjamin 1974c: 1096, 1098). Benjamin might have planned to reconsider the notion of sign and mark in his envisaged theory of "trace". However, his intention to develop a philosophical determination of "trace" in opposition to "aura" (Benjamin 1974c, 1102) was not fulfilled. The relationship between diverse "traces" (Benjamin 1974d: 611-613, 627) and the auratic experience was not elucidated in the new version of the essay.

At the same time, however, Benjamin continued his reflexions on colour and shame in his Commentary on Brecht's Poems (1939). He contrasted the gruesome city life of Mahagonny to the "stigma" of Baudelaire's Paris (Benjamin 1977g: 557). The marks (or stigmata) of Baudelaire's heroes concealed their socioeconomic misery under the guise of mythic figures. In contrast, the drunken apaches of Mahagonny rejoice audaciously "without shame, either false or genuine" in the dominance of dollars under which they are 
"flayed". They recognise God only as a "reduced" one "in a grey morning". Thus, Brecht stages the life of the "washed-up average man" in its economically bare state (Benjamin 1977g: 541, 543, 545). In another poem, he advises us to erase our personal traces or marks (such as grave monuments [Grabmal]) so we do not fall prey to the ruler (Benjamin 1977g: 555f.). In the poem Legend of the Origin of the Book Tao-te-Ching on Laotse's Road to Exile , he provides further advice on ways to escape our socioeconomic system: At the Hangu Pass, Laotse wrote his book and gave it to a customs man in exchange for supper and bed. This barter followed neither the so-called market mechanism nor stipulated toll rates. It came into existence solely because they did not miss the opportunity to "be friendly" to each other (Benjamin 1977g: 570-572).

In his presentation of this tale, Benjamin requires us to learn the way to live a "serene" life in the "bloodiest and darkest times" (1977g: 571). We might possibly find a way to pass through the misty network of guilt and debt without hiding behind blushing, flushing or other comical masks. Barter makes taxation difficult. Friendly barter differs not only from the generous gift of a friend in Kubin's story but also from the voluntary service of Scheerbart's people. I wonder if this friendly form of trade could have been adopted in the discussion of his Critique of Violence. If barter could be developed into an alternative exchange trading system, it might permeate the society and support independent methods of production and distribution when capitalist production is blocked by general strikes or other organised actions. Benjamin appreciated Georges Sorel's theory of the general strike only with respect to politics. He merely made a marginal reference to the economy (Benjamin 1977c: 195).

In Sorel's view, the general strike is a comprehensive "myth" of socialist ideas: an intuitive colouring of sentiments "with an intense life". Nevertheless, Sorel compared himself to a physicist because a physicist must be aware that his science will, at a later date, become as antiquated as a myth. Therefore, Sorel admitted that the anticipative colouring of actual events is inevitable (1999: 118, 140, 142, 40). Benjamin welcomed Sorel's theory of the proletarian general strike. However, he could not tolerate the bloody colour of "mythic violence" and opposed "divine violence" to it (Benjamin 1977c: 199). If he had looked into the whole spectrum of economic organisations, he might have developed his theory in another way. Similar to a physicist as he analyses the spectrum, Benjamin might have been able to clear the "mythic" appearance of our society through a chain of "serene" transactions. In the aforementioned fragment on money and rain (written also around 1921), he already thought about a moneyless and cloudless state (Benjamin 1972c: 941).

51 To extend his early theory in this direction, a closer reading of this and other fragments on capitalism would be required. We would also have to analyse the "serenity" of Kafka's stories (cf. Benjamin 2000: 113) by interpreting them in economic terms. These investigations are beyond the scope of this article. 


\section{BIBLIOGRAPHY}

Agamben, G. 1998. Homo sacer: Sovereign Power and Bare Life. Stanford: Stanford University Press.

Benjamin, W. 1972a. 'Old Forgotten Children's Books' [„Alte vergessene Kinderbücher"]. Gesammelte Schriften. Vol. III. Frankfurt a.M.: Suhrkamp, 14-22.

Benjamin, W. 1972b. News about Flowers [Neues von Blumen]. Gesammelte Schriften. Vol. III.

Frankfurt a.M.: Suhrkamp, 151-153.

Benjamin, W. 1972c. One-Way Street [Einbahnstraße]. Gesammelte Schriften. Vol. IV. Frankfurt a.M.: Suhrkamp, 83-148, 907-941.

Benjamin, W. 1972d. Berlin Childhood around 1900 [Berliner Kindheit um Neunzehnhundert]. Gesammelte Schriften. Vol. IV. Frankfurt a.M.: Suhrkamp, 235-304.

Benjamin, W. 1972e. Short Shadows (I) [Kurze Schatten I]. Gesammelte Schriften. Vol. IV. Frankfurt a.M.: Suhrkamp, 368-373.

Benjamin, W. 1972f. Outlook into Children's Books [Aussicht ins Kinderbuch]. Gesammelte Schriften. Vol. IV. Frankfurt a.M.: Suhrkamp, 609-615.

Benjamin, W. 1974a. Goethe's Elective Affinities [Goethes Wahlverwandtschaften]. Gesammelte Schriften . Vol. I. Frankfurt a.M.: Suhrkamp, 123-201.

Benjamin, W. 1974b. Origin of the German Mourning Play [Ursprung des deutschen Trauerspiels]. Gesammelte Schriften. Vol. I. Frankfurt a.M.: Suhrkamp, 203-430.

Benjamin, W. 1974c. The Paris of the Second Empire in Baudelaire [Das Paris des Second Empire bei Baudelaire]. Gesammelte Schriften. Vol. I. Frankfurt a.M.: Suhrkamp, 511-604, 1064-1212.

Benjamin, W. 1974d. On Some Motifs in Baudelaire [Über einige Motive bei Baudelaire]. Gesammelte Schriften. Vol. I. Frankfurt a.M.: Suhrkamp, 605-653.

Benjamin, W. 1974e. Central Park [Zentralpark]. Gesammelte Schriften. Vol. I. Frankfurt a.M.: Suhrkamp, 655-690.

Benjamin, W. 1974f. Theses on Philosophy of History [Über den Begriff der Geschichte]. Gesammelte Schriften. Vol. I. Frankfurt a.M.: Suhrkamp, 691-704, 1223-1266.

Benjamin, W. 1977a. On Language as Such and on Human Language [Über Sprache überhaupt und über die Sprache des Menschen]. Gesammelte Schriften. Vol. II. Frankfurt a.M.: Suhrkamp, 140-157.

Benjamin, W. 1977b. Fate and Character [Schicksal und Charakter]. Gesammelte Schriften. Vol. II. Frankfurt a.M.: Suhrkamp, 171-179.

Benjamin, W. 1977c. Critique of Violence [Zur Kritik der Gewalt]. Gesammelte Schriften. Vol. II. Frankfurt a.M.: Suhrkamp, 179-203.

Benjamin, W. 1977d. Robert Walser. Gesammelte Schriften. Vol. II. Frankfurt a.M.: Suhrkamp, 324-328.

Benjamin, W. 1977e. Franz Kafka. Gesammelte Schriften. Vol. II. Frankfurt a.M.: Suhrkamp, 408-438. Benjamin, W. 1977f. The Storyteller [Der Erzähler]. Gesammelte Schriften. Vol. II. Frankfurt a.M.: Suhrkamp, 438-465. 
Benjamin, W. 1977g. Commentary on Brecht's Poems [Kommentare zu Gedichten von Brecht]. Gesammelte Schriften. Vol. II. Frankfurt a.M.: Suhrkamp, 539-572.

Benjamin, W. 1977h. Painting and the Graphic Arts [Malerei und Graphik]. Gesammelte Schriften. Vol. II. Frankfurt a.M.: Suhrkamp, 602-603.

Benjamin, W. 1977i. Sign and Mark [Zeichen und Mal]. Gesammelte Schriften. Vol. II. Frankfurt a.M.: Suhrkamp, 603-607.

Benjamin, W. 1977j. Molière: The Imaginary Invalid [Molière: Der eingebildete Kranke]. Gesammelte Schriften. Vol. II. Frankfurt a.M.: Suhrkamp, 612-613.

Benjamin, W. 1977k. Program for a Proletarian Children's Theatre [Programm eines proletarischen Kindertheaters]. Gesammelte Schriften. Vol. II. Frankfurt a.M.: Suhrkamp, 763-769.

Benjamin, W. 1982. Gesammelte Schriften. Vol. V. Das Passagen-Werk. Frankfurt a.M.: Suhrkamp.

Benjamin, W. 1985a. On Shame [Über die Scham]. Gesammelte Schriften. Vol. VI. Frankfurt a.M.: Suhrkamp, 69-71.

Benjamin, W. 1985b. Capitalism as Religion [Kapitalismus als Religion]. Gesammelte Schriften. Vol. VI. Frankfurt a.M.: Suhrkamp, 100-103.

Benjamin, W. 1985c. Colour, Considered from the Perspective of the Child [Die Farbe vom Kinde aus betrachtet]. Gesammelte Schriften. Vol. VI. Frankfurt a.M.: Suhrkamp, 110-112.

Benjamin, W. 1985d. On the Surface of Plainly Illustrated Books [Über die Fläche des unfarbigen Bilderbuches]. Gesammelte Schriften. Vol. VI. Frankfurt a.M.: Suhrkamp, 112-113.

Benjamin, W. 1985e. For a Work on the Beauty of Colourful Pictures in Children's Books [Zu einer Arbeit über die Schönheit farbiger Bilder in Kinderbüchern]. Gesammelte Schriften. Vol. VI. Frankfurt a.M.: Suhrkamp, 123-125.

Benjamin, W. 1989a. The Rainbow [Der Regenbogen]. Gesammelte Schriften. Vol. VII. Frankfurt a.M.: Suhrkamp, 19-26, 560-564.

Benjamin, W. 1989b. The Work of Art in the Age of Its Technical Reproducibility [Das Kunstwerk im Zeitalter seiner technischen Reproduzierbarkeit]. Gesammelte Schriften. Vol. VII. Frankfurt a.M.: Suhrkamp, 350-384, 661-690.

Benjamin, W. 1989c. Berlin Childhood around 1900 [Berliner Kindheit um Neunzehnhundert]. Gesammelte Schriften. Vol. VII. Frankfurt a.M.: Suhrkamp, 385-433.

Benjamin, W. 1996-2000. Selected Writings. 4 vols. Cambridge: Harvard University Press. Benjamin, W. 1999. Arcades Project. (tr.) H. Eiland and K. McLaughlin. Cambridge: Harvard University Press.

Benjamin, W. 2000. Gesammelte Briefe. Vol. VI. Frankfurt a.M.: Suhrkamp.

Brüggemann, H. 2007. Walter Benjamin über Spiel, Farbe und Phantasie. Würzburg: Königshausen \& Neumann.

Burty, Ph. 1879. Charles Méryon, Sailor, Engraver, and Etcher. London: The Fine Art Society.

Caygill, H. 1998. Walter Benjamin: The Colour of Experience. London: Routledge.

Cohen, H. 1982. Ästhetik des reinen Gefühls. Vol. 1. Hildesheim / New York: Georg Olms Verlag. Fenves, P. 2011. The Messianic Reduction: Walter Benjamin and the Shape of Time. Stanford: Stanford University Press. 
Goethe, J.W.G. 1991. Zur Farbenlehre. Sämtliche Werke. Vol. 1-23-1. Frankfurt a.M.: Deutscher Klassiker Verlag.

Katz, D. 1911. Die Erscheinungsweisen der Farben und ihre Beeinflussung durch die individuelle Erfahrung. Leipzig: Barth.

Klages, L. 1974. Sämtliche Werke. Vol. III. Bonn: Bouvier.

Kubin, A. 1968. Die andere Seite. Munich: Nymphenburger Verlagshandlung.

Kuehni, R.G. 2008. Philipp Otto Runge's Color Sphere. URL: http://www.iscc.org/pdf/RungeFarbenKugel.pdf

Lonitz, H. (ed.). 1995. Theodor W. Adorno Walter Benjamin Briefwechsel 1928-1940. Frankfurt a.M.: Suhrkamp.

Matsui, T. 2008. Walter Benjamin und die Kunst des Graphischen. Berlin. URL: http://edoc.huberlin.de/docviews/abstract.php?lang=ger\&id=29120

Matsui, T. 2010a. Die Stadt als das Theatrer der Farben. A paper given at the 12th IVG Congress in Warsaw.

Matsui, T. 2010b. More Light on 'Bare Life': Goethe's Elective Affinities as a Comedy of Biopolitics. A paper given at the 34th Annual Conference of the German Studies Association. Oakland, California.

Matsui, T. 2011a. Shohyo [Book Review of] Asai Kenjiro Hen [ed.]: Walter Benjamin Collection I-V. In Moruforogia. Gete to Shizenkagaku 33, 112-121.

Matsui, T. 2011b. From Lavoisier to Dalton and Davy: Towards the Complete Decipherment of Goethe's Elective Affinities. Conference abstracts, University of Bergen. URL: http://www.uib.no/ filearchive/abstracts-literature-and-chemistry.pdf, 7-8.

Schumacher, H. 1982. Die Andere Seite (1909) von Alfred Kubin. In Spiegel im dunklen Wort. Analysen zur Prosa des fruhen 20. Jahrhunderts. (ed.) W. Freund/H. Schumacher. Frankfurt a.M./ Bern: Peter Lang, 9-34.

Simmel, G. 1989a. On Social Differenciation [Über sociale Differenzierung]. Gesamtausgabe. Vol. II. Frankfurt a.M.: Suhrkamp, 109-295.

Simmel, G. 1989b. Philosophy of Money [Philosophie des Geldes]. Gesamtausgabe. Vol. VI. Frankfurt a.M.: Suhrkamp, 7-716.

Simmel, G. 1990. Philosophy of Money. Trans. T. Bottomore and D. Frisby. London / New York: Routledge.

Simmel, G. 1995. The Metropolis and Mental Life [Die Großstädte und das Geistesleben]. Gesamtausgabe. Vol. VII. Frankfurt a.M.: Suhrkamp, 116-131.

Simmel, G. 1999. The View of Life [Lebensanschauung]. Gesamtausgabe. Vol. XVI. Frankfurt a.M.: Suhrkamp, 209-425.

Sorel, G. 1999. Reflexions on Violence. Cambridge: Cambridge University Press.

Weber, S. 2008. Benjamin's -abilities. Cambridge: Harvard University Press. 


\section{NOTES}

1. I prefer this translation of "A Glimpse into Children's Books" because the original title ( Aussicht ins Kinderbuch) is reminiscent of the phrase "Aussicht in die Zukunft" (outlook for the future). Although the English translations (Benjamin 1996-2000; Benjamin 1999) are very helpful, I do not refer to them in the text of this article because I modified a good numbers of words in my quotations.

2. Unlike Caygill (1998) and Brüggemann (2007), I regard the observation of these appearances (the phenomenological reduction of colour constancy) as the essential complement to Benjamin's dichotomy of line and colour.

3. Benjamin probably had the cloudy sky of Raphael's Madonna of Foligno and Kandinsky's apocalyptic vision of the Deluge (Composition VI) in mind when he spoke of painterly “composition”; cf. Matsui (2008: 221, 231f., 298f.).

4. Runge's remark on colour constancy is translated by Kuehni (2008: 72).

5. Fenves (2011: 69) provided an interesting phenomenological reading of this text, although he did not see its significance for Benjamin's theory of mark. I will analyse Benjamin's notion of the expressionless [das Ausdruckslose] on other occasions.

6. Thanks to a comment on my paper (2010b), I became motivated to investigate Simmel's influence on Benjamin's notion of "bare life". This article examines its terminological formation. I do not exclude the possibility that he later used it, as interpreted by Agamben (1998), in critical response to the political theory of Carl Schmitt.

7. Benjamin's criticism of this novel is based on a peculiarly distorted interpretation. Goethe composed its plot as a satire on scientists such as Newton, Watt, Count Rumford, Marie Lavoisier, Joseph Priestley and Thomas Young. However, its protagonists are "mythic" figures because they personify the four elements: Eduard (earth and Saturn), Ottilie (fire, light or Luna), Charlotte ( air) and the Captain (water). See Matsui (2011b).

8. Benjamin's fragment On Shame offers a theologically oriented revaluation of the coloured face without correcting Goethe's aesthetic prejudice against coloured skin as a whole.

9. Other "traits" of capitalism discussed by Benjamin have been analysed by Weber (2008: 250-267). He follows their relationship to the notes on fashion in The Arcades Project. In this paper, I follow another thread of associations via Simmel and other German authors.

10. This relation to Simmel's analogy in Matsui (2010a) was only noted impressionistically and without benefit of correct analysis.

11. Benjamin describes a similar overlap of motherly rhythm and mechanical beats in the first text of Berlin childhood around 1900 (1989c: 386).

12. The sandstone statues on the "Bridge of Hercules" (1989c: 395) had originally been placed on a bridge (Herkulesbrücke) over the ditch at the side of the stock exchange (near Hackescher Markt). After the demolition of that bridge, the statues were used to decorate a bridge over Landwehrkanal, which was subsequently renamed Herkulesbrücke. Benjamin seems to have compared the weathered statues of Hercules with the worn-out state of the German economy during the Great Depression by invoking the legend of the golden apples.

13. I pointed out this relationship briefly in Matsui (2011a).

14. Benjamin's notion was obviously inspired by Hermann Cohen's aesthetics (Brüggemann 2007: 150). He must have been aware that Cohen spoke of the mythic nature of Male based on Gottfried Semper's theory of style (cf. Cohen 1982: 377f., 62f.). Semper described the development of Maori art in his book (Matsui 2008: 292). 


\section{ABSTRACTS}

Benjamin's early aesthetics reconsiders the meaning of line and colour by observation of their relationships to the signs of guilt and the scrawls of 'innocent' children. Transparent colours found in illustrated children's books and the transiency of facial blushing caused Benjamin to hypothesise about certain redemptive effects of invisible rays on the turbid appearance of sinstained or disgraced creatures. He further developed these ideas by his critical reading of Simmel's philosophy. Simmel used analogies of colour and blood circulation to characterise law and economy as special 'forms' of life which transcend life itself and impose their quantitative evaluations (fine, reward etc.) on individuals. In Benjamin's view, those who become familiar with the notion of schuld (guilt/debt) become obedient to those forms in the 'fog' of mythic fate. The 'flâneur' exemplified such obedience in the lap of the arcades. He was dependent, like an embryo, on the fertility of our debt-producing economy. Benjamin tried to expose flâneurs to awakening illumination by staging the arcades (together with his own bourgeois childhood) in a changing light. He forces us to read their reactions to the threatening forces in the colour of their faces.

Les premiers écrits esthétiques de Walter Benjamin reviennent sur la signification des lignes et des couleurs en les mettant en relation avec les signes de culpabilité et les dessins d'enfants « innocents». Comparant les couleurs transparentes des livres pour enfants et le rougissement temporaire d'un visage, Benjamin suggère que des rayons invisibles ont des effets rédempteurs sur l'apparition troublée de créatures déchues ou souillées par le péché. Il approfondit ces idées par une lecture critique de la philosophie de Simmel. Ce dernier use en effet d'analogies avec les couleurs et la circulation sanguine pour caractériser le droit et l'économie comme des " formes » de vie spécifiques, qui transcendent la vie elle-même et imposent aux individus leurs modes d'évaluation quantitatifs (fin, récompense, etc.). Dans une perspective benjaminienne, ceux qui cèdent à la notion de Schuld (culpabilité/dette) finissent par obéir à ces formes, plongés dans le «brouillard» du destin mythique. Le «flâneur» illustre une telle obéissance à travers sa déambulation dans les passages parisiens. Tel un embryon, il est dépendant de la fertilité de notre économie productrice de dettes. Benjamin essaye de réveiller les flâneurs par l'illumination, en plongeant les passages (de même que son enfance bourgeoise) dans une lumière changeante. Il nous pousse ainsi à lire leurs réactions face aux forces qui les menacent dans les couleurs de leurs visages.

\section{INDEX}

Mots-clés: Benjamin (Walter), Simmel (Georg), destin, couleur, argent

Keywords: Benjamin Walter, Simmel Georg, fate, colour, money 


\section{AUTHOR}

\section{TAKAOKI MATSUI}

Independent scholar, Takaoki Matsui studied Social Sciences at the University of Tokyo and earned his PhD at Humboldt University in Berlin. His publications include articles on Benjamin, Goethe, and the visual arts. He is currently working on a study of Goethe's novel, Elective Affinities. 